\title{
Effect of Seasonal Variations on Distribution of Parasites in Camels at Assiut Locality
}

Barakat Shehata Abd-EImaleck*

Zoology Department, Faculty of Science, Assiut University, Assiut-71516, Egypt

"Corresponding author: Barakat Shehata Abd-Elmaleck, Zoology Department, Faculty of Science, Assiut University, Assiut-71516, Egypt, Tel: 0201113532752; Fax: 002088342708; E-mail: barakatshehata@yahoo.com

Rec date: Aug 18, 2015; Acc date: Dec 04, 2015; Pub date: Dec 07, 2015

Copyright: ( 2015 Elmaleck BSA. This is an open-access article distributed under the terms of the Creative Commons Attribution License, which permits unrestricted use, distribution, and reproduction in any medium, provided the original author and source are credited.

\begin{abstract}
Throughout four successive seasons (winter, spring, summer and autumn), one hundred and ninety five camels (Camelus dromedarius) from slaughtered houses in different regions at Assiut governorate were examined for protozoa parasites in blood and muscles. These parasites were Trypanosoma evansi, Trypanosoma type 1. (n.sp.) Babesia sp, Theileria cameli in blood and Sarcosystis sp. in muscles.
\end{abstract}

The prevalence of infection for the different parasites in both blood and muscles was also studied through the different seasons.

Generally Sarcosystis sp. was represented the highest incidence of infection (55.38\%) in the present study especially in spring (81.08\%). The lowest incidence of infection was represented in Trypanosoma evansi (2.5\%). At the same time the lowest incidence through different seasons was represented in Theileria cameli and Trypanosoma evansi $(4.83 \%)$ in autumn.

Keywords: Successive seasons; The prevalence; Highest incidence; Lowest incidence; Autumn

\section{Introduction}

Many reports on Sarcocystis sp. infections among different vertebrates including even man were recorded [1-7].

Many tick species, known to be vectors of diseases of man and his livestock, were found to infest camels, cattle, sheep and goats in different Kingdom Regions of Saudia Arabia [8]. Trypanosma evansi is the causative agent of surra, one of the most common and widespread of the trypansomal diseases. Trypanosomes can infect most mammals, although horses and camels are the principal hosts and represent the most significant sources of economic loss. Surra is endemic in many parts of Africa, Asia, and South America where thousands of animals die during disease outbreaks each year. Although not usually considered of zoonotic concern, one case of human infection with $T$. evansi recently has been documented in India [9].

Hemoparasites known to infect bovine erythrocytes and cause anemia include organisms from the genera Anaplasma, Eperythrozoon, Babesia, and Theileria. Theilerial parasites infect a broad range of wild and domestic artiodactyls throughout the world with highest prevalence in tropical and subtropical climates of Africa, Europe, Australia, and Asia [10,11].

So that, the aim of the present work is to know the effects of the seasonal variation on the distribution of different parasites in camels at Assiut and their prevalence incidence in different seasons.

\section{Material and Methods}

Blood samples and muscles of three different parts of camels (Camelus dromedarius) examined for protozoan parasites. The examined camels were collected from different localities of Slaughter houses at Assiut city. The freshly collected blood samples collected in a tube coated with EDTA. Thick and thin blood smears were made for morphological examination of some protozoan parasites. Electron microscopic studies recorded as follow:-

\section{TEM}

Few drops from infected blood and parts of muscles immediately fixed in $3 \mathrm{ml}$. of $3 \%$ glutaraldehyde solution in phosphate buffer $(\mathrm{PH}$ 7.2), for $24 \mathrm{hrs}$ and Kept at $4^{\circ} \mathrm{C}$ in refrigerator. The samples were post fixed in 1\% Osmium tetroxide in phosphate buffer (PH 7.2, 300 mom), for 30 minutes and washed several times with phosphate buffer solution. The samples were then embedded in Epon which can preserve in structure from distortion during processing then ultra-thin sections were cut by an Ultra microtome and examined by JEOL, 100 CXII operating at $80 \mathrm{KV}$ (TEM).

\section{SEM}

For scanning electron microscopy of infected blood and muscles; few drops or a part of infected muscles were fixed in $3 \%$ Glutaraldehyde in buffer for $24 \mathrm{hrs}$. Specimens were washed three times in Phosphate buffer and post fixed in 1\% Osmium tetroxide for 2 hours and then washed in the same buffer. They were Dehydrated in different grades of ethyl alcohol and then mounted on special holders and coated with gold. Then they were examined in a JSM-T 200 L.V. 5400 Scanning Electron Microscopy (SEM). 
Citation: Elmaleck BSA (2016) Effect of Seasonal Variations on Distribution of Parasites in Camels at Assiut Locality . J Veterinar Sci Technol 7: 279. doi:10.4172/2157-7579.1000279

Page 2 of 6

\section{Results}

\section{Prevalence \& seasonal variation}

Survey and incidence of protozoan parasites in camels: One hundred and ninety eight Camelus dromedarius examined throughout four different seasons (From May 2011-25 October 2012).

Examined camels were found harboring muscles and blood protozoa:

\section{Muscles parasites}

Sarcosystis sp. 108 (55.3\%) [Figures (1 and 2)]

\section{Blood parasites}

Trypanosoma evansi 5 (2.5\%) [Figures (3 and 4)]

Trypanosoma type 1(n.sp.) 19 (9.7\%) [Figures (5 and 6)]

Babesia sp. $\quad 51(26.1 \%) \quad$ [Figures (7 and 8)]

\section{Theileria cameli $12(6.1 \%) \quad$ [Figures (9 and 10)]}

Generally Sarcosystis sp. was represented the highest incidence of infection $(55.38 \%)$ in the present study especially in spring $(81.08 \%)$. The lowest incidence of infection was represented in Trypanosoma evansi (2.5\%). At the same time the lowest incidence through different seasons was represented in Theileria cameli and Trypanosoma evansi $(4.83 \%)$ in autumn.

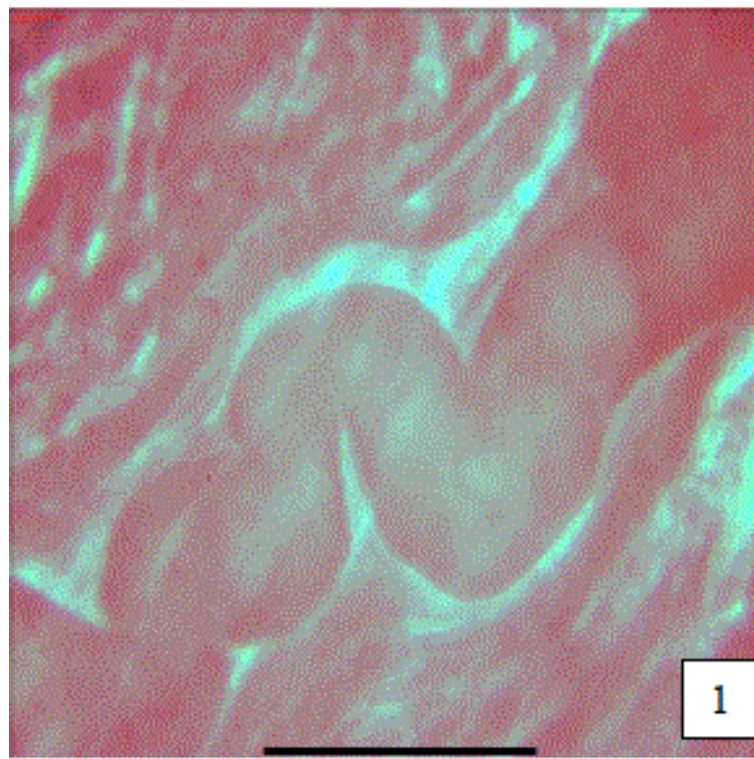

\section{$20 \mathrm{um}$}

Figure 1: Photomicrograph showing cyst of Sarcosystis sp. in the esophagus muscles of Camelus dromedarius stained with Acetoacetic alum carmine.

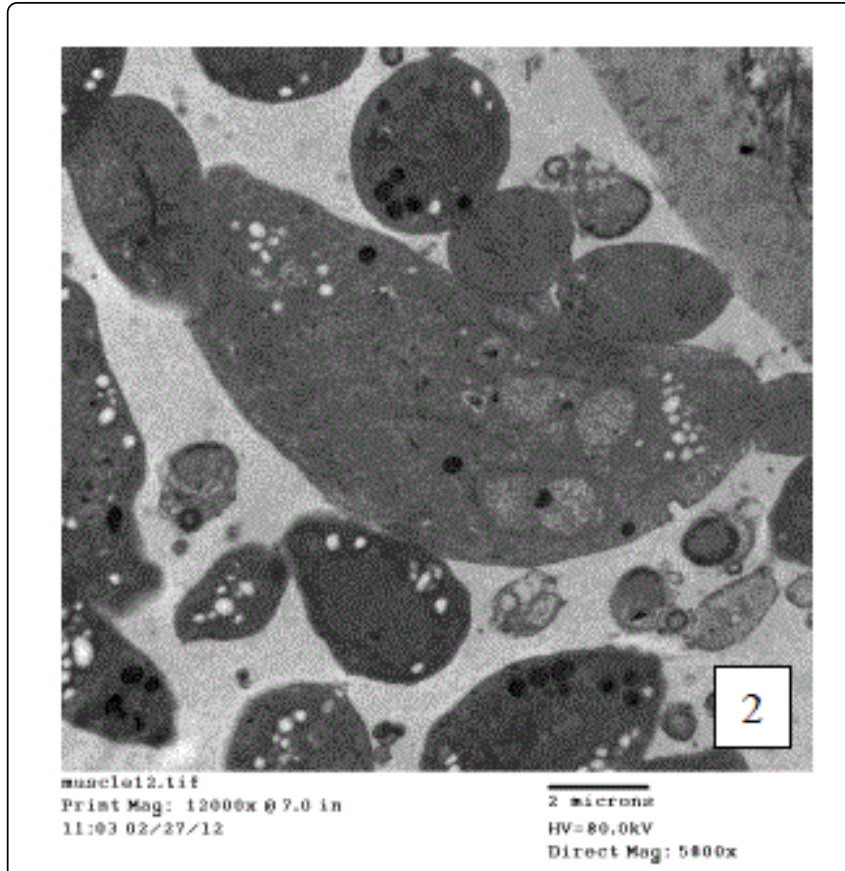

Figure 2: Transmission electron micrograph of Sarcosystis sp. in muscles of Camelus dromedaries.

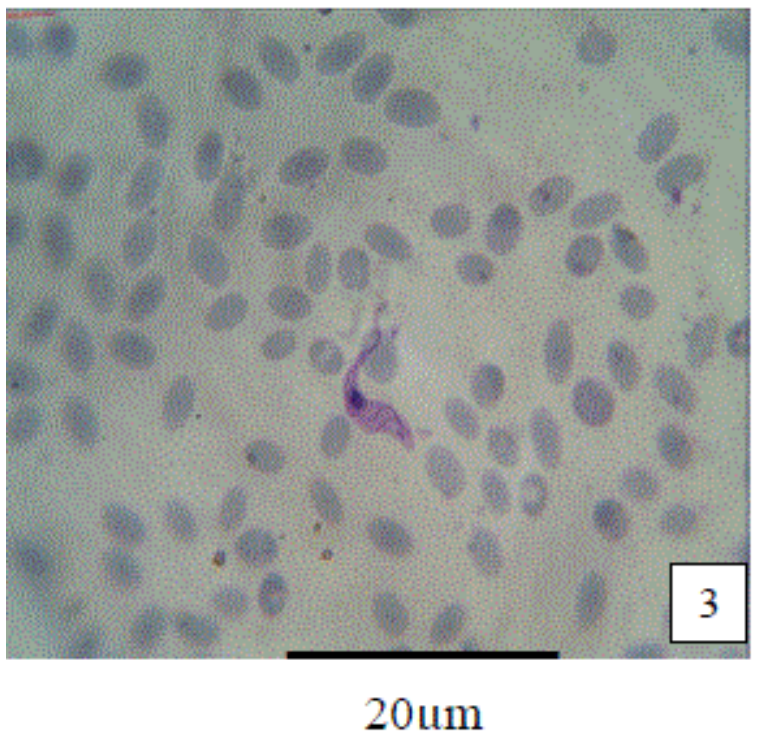

Figure 3: Photomicrograph showing Trypanosoma evansi in the blood cells of Camelus dromedarius stained with Geimsa stain.

On one hand, Trypanosoma evansi was disappeared in spring and summer and on the other hand, Trypanosoma type 1. (n. sp.) was disappeared in spring and winter. But on the other side, Babesia sp. appeared through the four seasons with high incidence ratios in autumn and winter $(28.8 \%$ and $28.2 \%)$ respectively and low incidence in spring and summer (18.9\% and $24.5 \%)$ respectively. 
Citation: Elmaleck BSA (2016) Effect of Seasonal Variations on Distribution of Parasites in Camels at Assiut Locality . J Veterinar Sci Technol 7: 279. doi:10.4172/2157-7579.1000279

Page 3 of 6

Hence, distribution and differentiation of the infection ratios with protozoa and presence of new parasites for the first time in Camelus dromedarius throughout the different seasons can be explained on the basis of feeding habits and their living in herds with different animals (Cattle's, sheep's and goats).

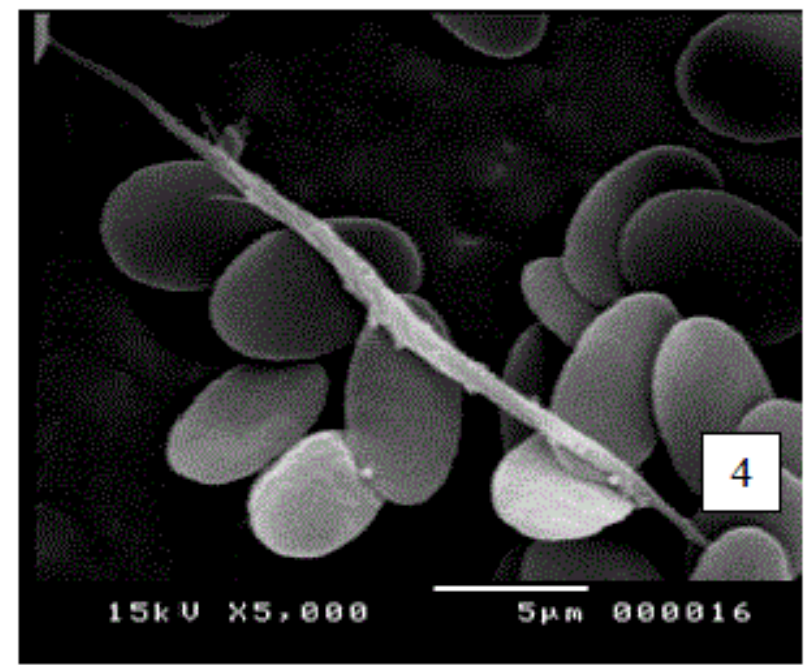

Figure 4: Scanning electron micrograph of Trypanosoma evansi. in the blood cells of Camelus dromedaries.

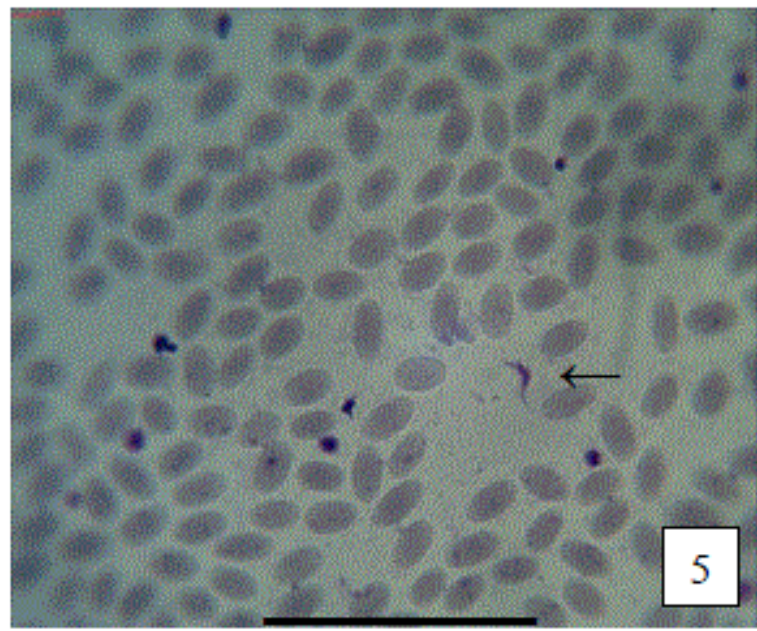

$2011 \mathrm{~m}$

Figure 5: Photomicrograph showing Trypanosoma type (1) (n. sp.) in the blood cells of Camelus dromedarius stained with Geimsa stain.

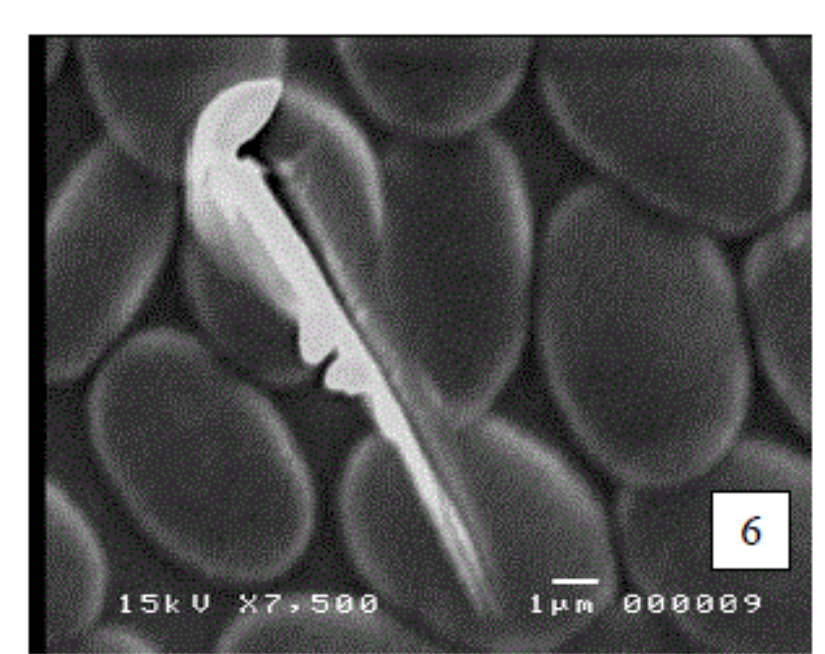

Figure 6: Transmission electron micrograph of Trypanosoma type (1) (n. sp.).

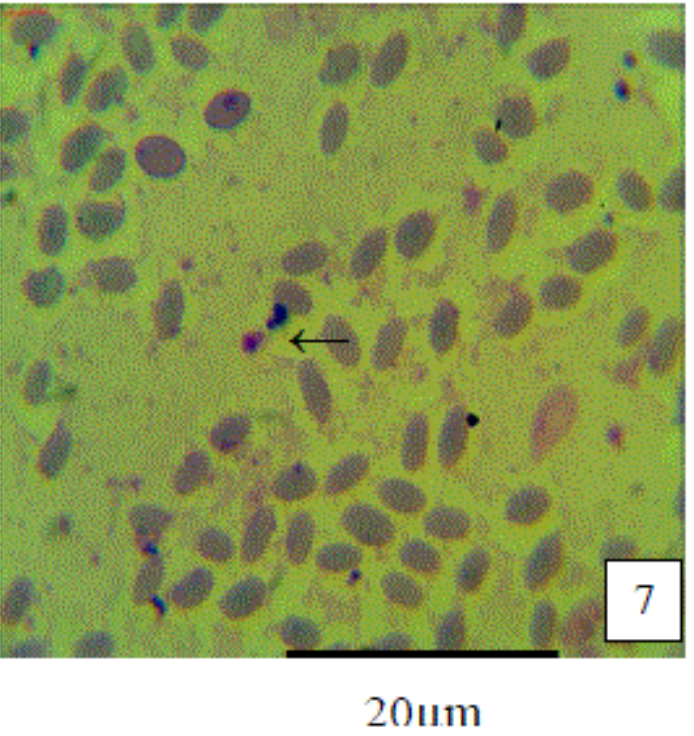

Figure 7: Photomicrograph showing Babesia sp. in the blood cells of Camelus dromedarius stained with Geimsa stain.

Table (1) and Histogram (1) show the incidence of different parasites infecting Camelus dromedarius during the different seasons.

\begin{tabular}{|c|c|c|c|c|c|c|c|c|c|c|c|c|}
\hline \multirow[b]{2}{*}{ Parasites } & \multicolumn{3}{|l|}{ Winter } & \multicolumn{3}{|l|}{ Spring } & \multicolumn{3}{|l|}{ Summer } & \multicolumn{3}{|l|}{ Autumn } \\
\hline & $\begin{array}{l}\text { No. } \\
\text { examined }\end{array}$ & $\begin{array}{l}\text { No. } \\
\text { infected }\end{array}$ & Percentage & $\begin{array}{l}\text { No. } \\
\text { examined }\end{array}$ & $\begin{array}{l}\text { No. } \\
\text { infected }\end{array}$ & Percentage & $\begin{array}{l}\text { No. } \\
\text { examined }\end{array}$ & $\begin{array}{l}\text { No. } \\
\text { infected }\end{array}$ & Percentage & $\begin{array}{l}\text { No. } \\
\text { examined }\end{array}$ & $\begin{array}{l}\text { No. } \\
\text { infected }\end{array}$ & Percentage \\
\hline
\end{tabular}


Citation: Elmaleck BSA (2016) Effect of Seasonal Variations on Distribution of Parasites in Camels at Assiut Locality . J Veterinar Sci Technol 7: 279. doi:10.4172/2157-7579.1000279

Page 4 of 6

\begin{tabular}{|c|c|c|c|c|c|c|c|c|c|c|c|c|}
\hline $\begin{array}{l}\text { Sarcosystis } \\
\text { sp. }\end{array}$ & 39 & 29 & 74.3 & 37 & 30 & 81.08 & 57 & 28 & 49.1 & 62 & 24 & 38.7 \\
\hline Tr. evansi & & 2 & 5.12 & & 0 & 0 & & 0 & 0 & & 3 & 4.83 \\
\hline $\begin{array}{l}\text { Tr. type } 1 . \\
\text { (n. sp.) }\end{array}$ & & 0 & 0 & & 0 & 0 & & 3 & 5.2 & & 16 & 25.8 \\
\hline Babesia sp. & & 11 & 28.2 & & 7 & 18.9 & & 14 & 24.5 & & 16 & 25.8 \\
\hline $\begin{array}{l}\text { Theileria } \\
\text { cameli }\end{array}$ & & 3 & 7.69 & & 2 & 5.4 & & 4 & 7.01 & & 3 & 4.83 \\
\hline $\begin{array}{l}\text { Theileria } \\
\text { cameli }\end{array}$ & & 3 & 7.69 & & 2 & 5.4 & & 4 & 7.01 & & 3 & 4.83 \\
\hline
\end{tabular}

Table 1: Shows distribution of muscles and blood parasites through different seasons in Camelus dromedaries.

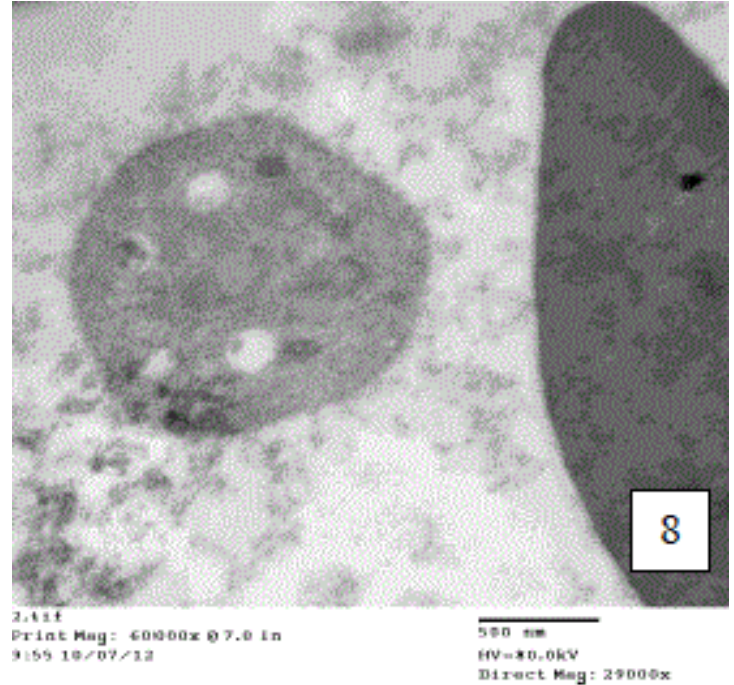

Figure 8: Transmission electron micrograph of Babesia sp. showing more than one vacuoles in the blood cells of Camelus dromedarius.

\section{Discussion}

The coccidian nature of Sarcocystis was achieved by a series of experimental transmission of the cyst contents from goat muscles, in which a high prevalence of these parasites had been reported [12,13]. Cysts were only formed within muscles of the intermediate hosts and these were described as sarcocystis which usually indicated a broad host range as well as world-wide distribution $[14,15]$. The present study confirmed that there was a variable rate of natural infection in the muscles of the examined hosts, where 108(55.3\%) animals were infected with microscopic Sarcocystis. These results are in low with those recorded Riyadh by Al-Quraishy et al. [16] with a prevalence of $91 \%$ and $89 \%$, respectively. Also, Woldemeskel and Gebreab [17] recorded a prevalence of $90 \%$ in Ethiopia, whereas, Latif et al. [18] reported $97.4 \%$ infection rate in Iraq. On the contrary, lower rates of natural infection with Sarcocystis were reported by some authors [19-23] agree with the present study. The current study showed that $S$. meisheri distributed in the different tissues of camels with a variable rates. The highest infection rate was recorded in esophagus muscles
(62\%) followed by abdominal muscles (52.2\%) and tongue $(51.25 \%)$. This distribution was studied previously by Singh [24] he stated that, esophagus is the most infected organs among all other tissues. Singh et al. [25] reported that a total of $79.3 \%$ of esophagus and $72.4 \%$ of tails had sarcocystis in older goats, but their prevalence in younger animals was $40.0 \%$ in esophagi and none in tails. The differences in intensities and organ distribution of the examined hosts may be due to oocyst contamination, isolates responsible for the infection, differences in the ecological and nutritional status of the hosts that may lead to variations in the immunity against infection and parasites as well $[26,27]$.

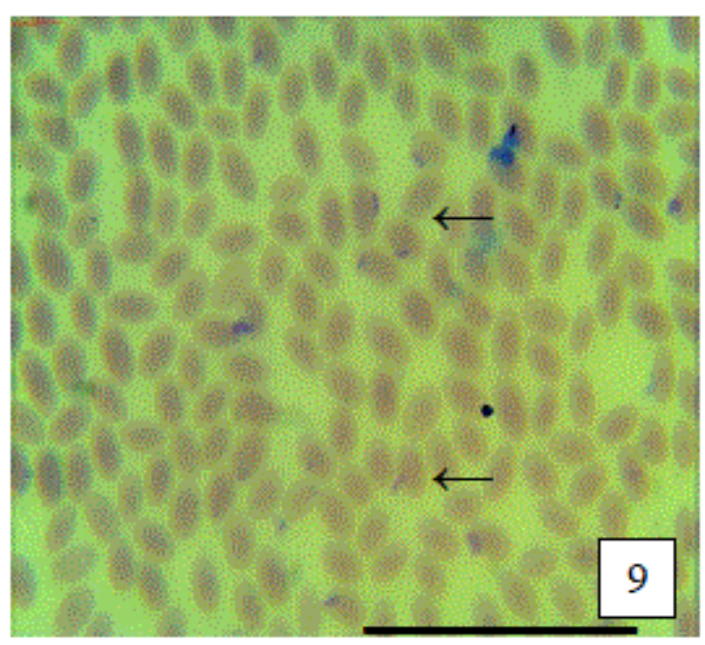

$2011 \mathrm{~m}$

Figure 9: Photomicrograph showing Theileria cameli in the blood cells of Camelus dromedarius.

In Egypt, T. evansi is an enzootic in camels with high prevalence of antibody and genome detection by PCR assays among slaughtered camels as reported at the main Abattoir of the Cairo governorate [28,29]. Mohamoud et al. [30] revealed that, many camels were negative by blood examination but positive by PCR, which may be related to low parasitemia and/or low sensitivity of the thin blood smear technique and indicates that low parasitemia might be due to early infections, chronic infection and/or lower strain virulence. 
Citation: Elmaleck BSA (2016) Effect of Seasonal Variations on Distribution of Parasites in Camels at Assiut Locality . J Veterinar Sci Technol 7:

Page 5 of 6

Furthermore, it was reported that the detection of less than $2.5 \times$ 1,000000 trypanosomes per $\mathrm{ml}$ in blood samples by microscopy is not feasible [31], and this explain the low incidence (2.5\%) of the parasite through one season only and its disappeared through the rest of seasons in the present study beside that, some drugs which given in the veterinary hospitals for these animals.

Blood parasites are common in domestic animals, rodents and human beings, may be fatal and mostly transmitted by ectoparasites to human and other [32-34]. Babesi speciesare transmitted by ticks to susceptible animals, rodents and humans [35,36]. Although a number of different animals serve as reservoirs of Babesia species however rodents are at the top [36]. In the present work Babesia sp. was infected camels with different rates in the different seasons, autumn, winter, summer and spring $(28.8 \%, 28 \%, 24.5 \%$ and $18.9 \%)$ respectively. $\mathrm{n}$ contrast higher infection rates had been observed by different research workers working in various geographical regions.

Theileria sp. is transmitted by ticks acting as biological vectors. Rhipicephalus appendiculatus is the most important vector for $T$. parva, but $R$. Zembeziensis and $R$. duttoni carry this organism in parts of Africa. T. annulata is transmitted by ticks in the genus Hyalomma. Hyalomma spp. are also the vectors for T. lestoquardi, T. ovis and T. separata, while $T$. buffeli and $T$. sergenti are transmitted by Haemaphysalis sp. and T. mutans and T. velifera are transmitted by Amblyomma sp.Genus Rhipicephalus spread T. taurotragi. Ticks in the genus Rhipicephalus spread T. taurotragi. [37-42]. In the present study the parasite was accompanied to Babesia so that, it was appeared in all seasons with low different incidence $(7.69 \%, 7.01 \%, 5.4 \%$ and $4.83 \%)$ in winter, Summer, spring and autumn in respectively.

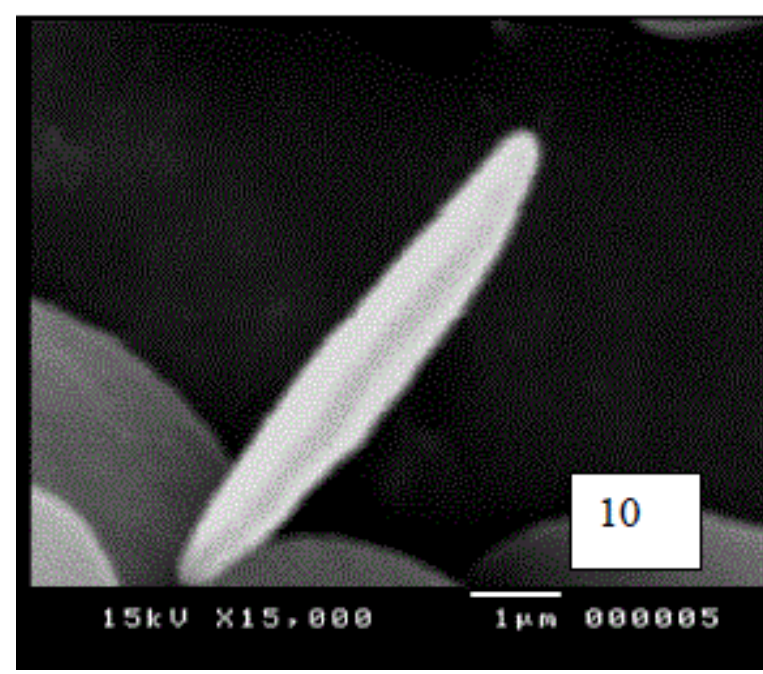

Figure 10: Scanning electron micrograph of cigarette shape of Theileria cameli in the blood cells of Camelus dromedaries.

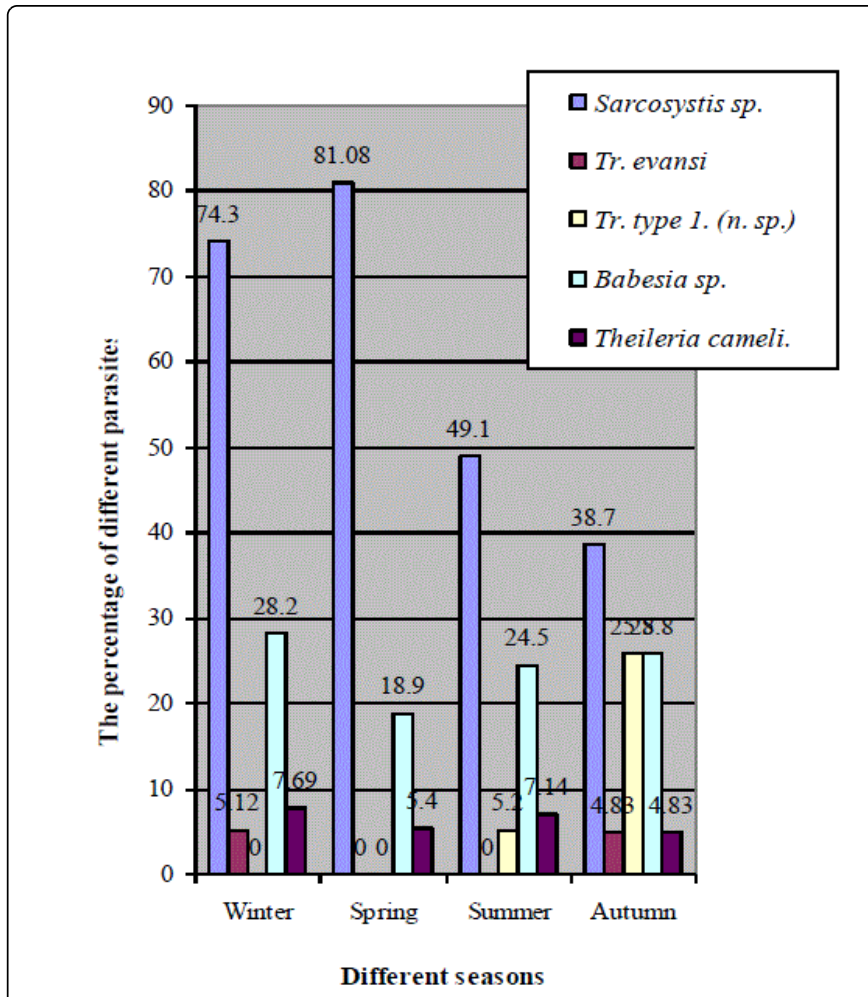

Histogram 1: Shows distribution of different parasites in Camels through different seasons.

\section{Conclusion}

The present study was showed that, the seasonal variation had a clear effect on the distribution of the parasites in camels either by disappearing of some species through the different seasons or appearing of new species in others.

Generally the prevalence values of some parasites were differentiated through the different seasons.

\section{References}

1. Mehlhorn H, Heydorn AO (1978) The Sarcosporidia (Protozoa Sporozoa): life cycle and fine structure. Adv Parasitol 16: 43-93.

2. Dubey JP, Kistner TP, Callis G (1983) Development of Sarcocystis in mule deer transmitted through dogs and coyotes. Canad J Zool 61: 2904-2912.

3. Entzeroth R, Chobotar B, Scholtyseck E, Neméseri L (1985) Light and electron microscope study of Sarcocystis sp. from the fallow deer (Cervus dama). Z Parasitenkd 71: 33-39.

4. Ghaffar FA, Hilali M, Scholtyseck E (1978) Ultrastructural study of Sarcocystis fusiformis (Railliet, 1897) infecting the Indian water buffalo (Bubalus bubalis) of Egypt. Tropenmed Parasitol 29: 289-294.

5. Abdel-Ghaffar F, Bashtar AR, Ashour MB, Sakran TH (1990) Life cycle of Sarcocystis gongyli Trinci 1911 in the shink Chalcides ocellatus and the snake Spalerosophis diadema. Parasitol Res 76: 444-450.

6. Abdel-Ghaffar F, Bashtar AR, El-Sayed M (1990) Electron microscopic studies on Sarcocystis infection in sheep in Upper Egypt. Bull Fac Sci Cairo Univ 58: 33-49.

7. Abdel-Ghaffar F, Al-Johany AM (2002) A light and electron microscope study of Sarcocystis mitrani (sp. Nov.) infecting the skink Scincus mitranus in the central region of Saudi Arabia. Parasitol Res 88: 102-106. 
8. Diab FM, Al-Khalifa MS, Al-Asgah NA, Hussein HS, Khalil GM (2006) Ticks infesting livestock in Saudi Arabia. Fauna of Arabia 22: 233-244.

9. WHO (2005) Human African trypanosomiasis (sleeping sickness) Weekly Epidemiological Record 81: 71-80.

10. Irvin AD (1987) Characterization of species and strains of Theileria. Adv Parasitol 26: 145-197.

11. Conrad PA, Waldrup KA (1993) Babesiosis and theileriosis in Freeranging and captive artiodactylids. In: Zoo and Wild Animal Medicine, Current Therapy (3 Edn) Fowler ME WB Saunders, Philadelphia, PA pp. 506-511.

12. Heydorn AO, Rommel M (1972) Contributions on the life cycle of Sarcosporidia. II. Dog and cat as vectors of cattle Sarcosporidia. Berl Munch Tierarztl Wochenschr 85: 121-123.

13. Dubey JP, Kerber CE, Granstrom DE (1999) Serologic prevalence of Sarcocystis neurona, Toxoplasma gondii, and Neospora caninum in horses in Brazil. J Am Vet Med Assoc 215: 970-972.

14. Melhorn H (2008) Encyclopedia of parasitology. (3rd Edn) Springer Verlag, Berlin.

15. Abdel-Ghaffar F, Mehlhorn H, Bashtar AR, Al-Rasheid K, Sakran T, et al. (2009) Life cycle of Sarcocystis camelicanis infecting the camel (Camelus dromedarius) and the dog (Canis familiaris), light and electron. Mic stud Parasitol Res 106: 189-195.

16. Al-Goraishi SAR, Bashtar AR, Al-Rasheid KAS, Abdel-Ghaffar FA (2004) Prevalence and ultrastructure of Sarcocystis species infecting camels (Camelus dromedarius) slaughtered in Riyadh city Saudi Arabia. Saud J Biol Sci 11: 135-140.

17. Woldemeskel M, Gebreab F (1996) Prevalence of sarcocysts in livestock of northwest Ethiopia. Zentralbl Veterinarmed B 43: 55-58.

18. Latif BM, Al-Delemi JK, Mohammed BS, Al-Bayati SM, Al-Amiry AM (1999) Prevalence of Sarcocystis spp. in meat-producing animals in Iraq. Vet Parasitol 84: 85-90.

19. Heydorn AO, Kirmsse $P$ (1996) Isolation and experimental transmission of Sarcocystis moulei Neveu-Lemaire, 1912. Berl Munch Tierarztl Wochenschr 109: 440-445.

20. Abdel-Ghaffar F, Hilali M, Scholtyseck E (1978) Ultrastructure study of Sarcocystis fusiformis (Railliet 1897) infecting the Indian water buffalo Bubalus bubalis of Egypt. Tropenmed Parasitol 29: 289-294.

21. Abdel-Ghaffar F, Shazly M, Ahmed A, Fayed M (1994) Ultrastructural study of muscle cysts of Sarcocystis sp. Infecting the Egyptian gecko, Tarentolaannularis with special reference to endodyogeny. J Union Arab Biol 2A: 371-389.

22. Fukuyo M, Battsetseg G, Byambaa B (2002) Prevalence of Sarcocystis infection in meat-producing animals in Mongolia. Southeast Asian J Trop Med Public Health 33: 490-495.

23. Nedjari M (2003) The occurrence of animal sarcocystosis in Algeria. Berliner und Münchener Tierärtzliche Wochenschrift 116: 139-141.

24. Singh L, Raisinghani PM, Pathak KM, Kumar D, Manohar GS, et al. (1991).

25. Singh KP, Shah HL (1990) Viability and infectivity of Sarcocystis capracanis of the goat after maintaining them at different temperatures. Indian J Anim Sci 60: 429-430.
26. Shazly MA (2000) Light and Electron microscopic studies on Sarcocystis infecting the Dromedaries in Saudi Arabia. Egypt J Zool 35: 273-285.

27. Abdel-Ghaffar F, Bashtar AR, Al-Quraishy S, Al Nasr I, Mehlhorn H (2009) Sarcocystis infecting reptiles in Saudi Arabia : 1-Light and electron microscopic study on Sarcocysts of Sarcocystis turcicii sp. nov. infecting the gecko Hemidactylus turcicus Linnaeus. Parasitol Res 104: 503-508.

28. Amer S, Ryu O, Tada C, Fukuda Y, Inoue N, et al. (2011) Molecularidentification and phylogenetic analysis of Trypanosoma evansi from dromedary camels(Camelus dromedarius ) in Egypt, a pilotstudy. Acta Trop 117: 39-46.

29. Zayed AA, Habeeb SM, Allam NAT, Ashry HMZ, Mohamed AHM, et al. (2010) A critical comparative study of parasitological and serological differential diagnostic methods of Trypanosoma evansi infections in some farm animals in Egypt. Am Eurasian J Agr Environ Sci 8: 633-642.

30. Elhaig MM, Youssef AI, El-Gayar AK (2013) Molecular and parasitological detection of Trypanosoma evansi in Camels in Ismailia, Egypt. Vet Parasitol 198: 214-218.

31. Herbert WJ, Lumsden WH (1976) Trypanosoma brucei a rapid matching methods for estimating the host's parasitemia. Exp Parasitol 40: 427-431.

32. Bossi D, Linhares A, Bergallo H (2002) Parasitic arthropods of some wild rodents from JuréiaItatins Ecological Station, state of São Paulo, Brazil. Mem Inst Oswaldo Cruz 97: 959-963.

33. Rios L, Alvarez G, Blair S, (2003) Serological and parasitological study and report of first case human babesiosis in Colombia. Rev Soc Bras Med Trop 36: 493-498.

34. Barreira J, Dorierossi M, Silva G, Pires F, Massard C, (2004) Avaliação clinico-parasitológica de Meriones unguilatus frente à infecção experimental com amostras modificadas de Babesia bovis e B.bigemina. Rev Bras Parasitol Vet 13: 230.

35. Homer MJ, Aguilar-Delfin I, Telford SR, Krause PJ, Persing DH (2000) Babesiosis. Clin Microbiol Rev 13: 451-469.

36. Karbowiak G (2004) Zoonotic reservoir of Babesia microti in Poland. Pol J Microbiol 53 Suppl: 61-65.

37. World Organization for Animal Health [OIE] (2009) Theilieriosis Paris OIE.

38. Irvin AD (1987) Characterization of species and strains of Theileria. Adv Parasitol 26: 145-197.

39. Dubey JP, Kerber CE, Granstrom DE (1999) Serologic prevalence of Sarcocystis neurona, Toxoplasma gondii, and Neospora caninum in horses in Brazil. J Am Vet Med Assoc 215: 970-972.

40. Heydorn AO, Rommel M (1972) Beiträge zum Lebenszyklus der Sarcosporidien II- Hund und Katze als Überträger der Sarcosporidien des Rindes. Berl Münch Tierärtztl Wschr 85: 121-123.

41. Epidemiology of Sarcocystis capracanis in goats at Bikaner, Rajasthan, India. Indian J Anim Sci 62: 1044-1045.

42. Melhorn H (2008) Encyclopedia of parasitology. (3rd Edn) Springer Verlag, Berlin. 